\title{
Fossil Nominalization Prefixes in Tibetan and Chinese
}

\author{
Guillaume Jacques \\ CNRS-CRLAO-INALCO-EHESS \\ rgyalrongskad@gmail.com
}

\begin{abstract}
This paper shows that both Tibetan and Old Chinese preserve lexicalized traces of several nominalization prefixes which are still productive in morphologically more conservative languages of the Trans-Himalayan family such as Rgyalrongic, which can thus serve as a model for analyzing other languages.
\end{abstract}

\section{Keywords}

Tibetan - Chinese - Rgyalrongic - Kiranti - Nominalization - Prefixation

\section{$1 \quad$ Introduction ${ }^{1}$}

In the Trans-Himalayan family (TH), the morphologically most complex languages, Rgyalrong and Kiranti, are endangered languages without a written literary tradition. A growing body of evidence suggests that this complex morphology is at least in part archaic (Jacques 2012a, DeLancey 2014, Jacques 2016c, Gong 2017), in particular because affixes that are nonproductive and in some cases only accessible through reconstruction (such as the sigmatic causative) in Tibetan and Chinese are still productive in Rgyalrong languages.

The present paper deals with another comparable case of recessive morphology in the literary languages, the sigmatic and velar nominalization prefixes. These prefixes, which are completely productive in various languages of the TH family, including Rgyalrong, Kiranti, Karbi, Jinghpo and Kuki-Chin (Konnerth 2016) are only attested in a handful of words in Tibetan and Old Chinese. Using evidence from Japhug to ascertain the precise meaning of these prefixes, this study proposes new etymologies and evaluates older proposals.

Rgyalrongic languages have a set of prefixes deriving non-finite verb forms, including participles, converbs and infinitives (Jacques 2014c, Sun 2014a, Jacques 2016b). In the present paper, two sets of participles, the velar (core argument) and sigmatic (oblique) participles are discussed.

\footnotetext{
1 The glosses follow the Leipzig Glossing Rules. Other abbreviations used here are: AUTO autobenefactive / spontaneous, DEM demonstrative, EMPH emphatic, INV inverse, LNK linker, PFV perfective, POss possessor, FACT factual, SENS sensory. 


\subsection{Velar Participles}

All Rgyalrong languages (Japhug, Tshobdun, Zbu and Situ) have a set participle prefixes in $\mathbf{k V}$ - used in particular to build participial relative clauses with subject or object relativization. There are slight differences between the languages (Sun 2006, Sun and Lin 2007, Jacques 2016b, Zhang 2016); this paper only includes data from Japhug, which are sufficient to illustrate the constructions shared by all Rgyalrong languages. ${ }^{2}$

The core argument participle prefixes in Japhug are ku- for subject (S/A) participle and $\mathbf{k} \boldsymbol{\gamma}$ - for object participle, and can be illustrated by examples (1) (intransitive subject, in a non-restrictive head-internal relative) (2) (transitive subject) and (3) (object and intransitive subject).

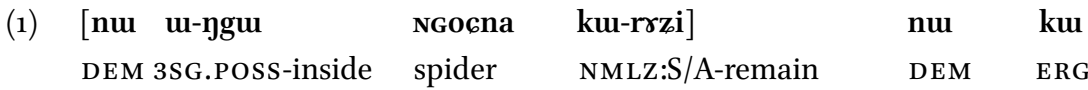

pju-mts ${ }^{\text {hrm tce, }}$

IPFV-hear LNK

'The spider, which stays inside, feels it' (26-mYaRmtsaR, 64)

(2) $\quad$ tum-xtsa $\quad$ u-ku-tsuß $\beta]$

INDEF.POSS-shoe 3SG.POSS-NMLZ:S/A-sew DEM 3SG.POSS-DAT

'(He told) the shoe sewer.' (2003tWxtsa, 12)

(3) $\quad[$ ta-si

INDEF.POSs-younger.sibling

[pul-ku-si] numu

PFV-NMLZ:S/A-die DEM pur-kr- $\beta d e]$

PFV-NMLZ:P-throw

pyrtcu

bird $\begin{array}{ll}\text { num } & \mathbf{u}-\mathbf{p}^{\mathbf{h}} \mathbf{e} \\ \text { DEM } & \text { 3SG.POSS-DAT }\end{array}$

nunu,

DEM

ci to-sci,

INDEF IFR-be.born

'The younger sister, who had been thrown away, who had died, was reborn as a bird' (qaCpa2002, 152)

Adjectival stative verbs need to take the participle ku- prefix to be used as attributes. The noun they modify is the head of the participial relative, which is generally head-internal as wuma zo $\mathbf{k}^{\mathbf{h}} \mathbf{a}$ ku-zru 'very splendid house' ('house that is very splendid/luxurious') in (4), as shown by the place of the intensifier wuma zo.

(4) [wuma

Really

tó-wy-tsum

IFR:UP-INV-take.way

'(The bird) took her away to a splendid house (in heaven)' (2003zrAntCW tWrme, 74) ui-ngu

3SG.POss-inside

nutcu

house NMLZ:S/A-be.strong

tce

LNK

DEM:LOC

The Japhug examples are taken from a corpus that is progressively being made available on the Pangloss archive (Michailovsky et al. 2014, http://lacito.vjf.cnrs.fr/pangloss/corpus/list_rsc.php?lg=Japhug). Middle Chinese is in Baxter's (1992) transcription but converted to IPA equivalents.

2 The participle prefixes are historically related to generic person and infinitive prefixes (Sun 2012, Sun 2014b, Jacques 2016a, Jacques 2018), but these are not discussed in this paper. 
In addition, there is a handful of lexicalized participles, where the vowel in the prefix has been lost and which appear as fricativized preinitials $\mathbf{x}$ - or $\gamma^{-}$in Japhug (see Table 1 from Jacques 2014a: 5). Among these, - zjyu 'opening, orifice' has cognates in Stau and Khroskyabs (Jacques et al. 2017: 609). Loss of vowel in velar prefixes is a regular sound change that is also observed on some nouns such as yzu 'monkey' and is conditioned by the absence of clusters on the second syllable (Jacques 2014a: 5 ). The fact that all non-lexicalized participles have ku- in Japhug is due to analogical restoration of the vowel.

The velar participle prefixes found in Rgyalrong languages have cognate prefixes in many TransHimalayan languages, including Bodo-Garo, Jinghpo, Kuki-Chin, Karbi and Kiranti (Konnerth 2014, 2016, DeLancey 2015). In some languages, such as Limbu, the velar nominalization prefixes co-occur with a nominalization suffix. The circumfix ke-...-pa/-ba serves as active participle (van Driem 1987: 199-202), as in (5), is an example of this type of construction.

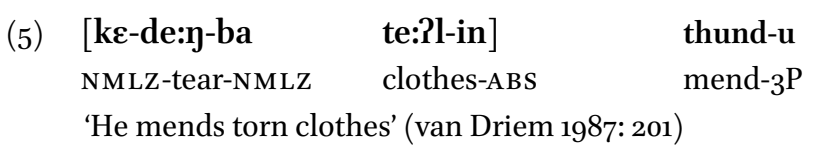

\begin{tabular}{llll} 
Table 1 & Irregular nominalizations in $\mathrm{\gamma}^{-}$and $\mathbf{x}-$ & \\
\hline noun & meaning & base verb & meaning \\
\hline yndzr $\beta$ & 'disastrous fire' & ndzr $\beta$ & 'burn' \\
- -jnas & 'disaster' & jas & 'be black' \\
- -jpju & 'orifice' & jfu & 'open (vi)' \\
-xso & 'empty thing' & so & 'be empty' \\
& & & \\
\hline
\end{tabular}

\subsection{Sigmatic Participles}

In addition to the velar prefixes, we also find in Rgyalrong languages oblique participle prefixes (in Japhug sr- , srz- or z-) and related converbial forms (Yanmuchu 2005, Sun 2014a, Jacques 2016b).

The oblique participles are fully productive, and can be applied to any verb, even stative verbs, to build adjunct participial relatives as in (6). They can be converted into nouns (in particular for instruments, such as srcu 'key' from the verb cu 'open') and even place names (there is for instance in Kamnyu village a place called znrryrma, a lexicalized locative participle from the verb nrryrma to call the rain').

(6) stu

Most

yu-nu

be:FACT-PL

'The (places) where they are the most numerous are the grasslands'. (19-qachGa mWntoR, 24) 
Among the syntactic roles that can be relativized with the oblique participle are instrumental adjuncts (7), dative arguments (8), comitative arguments (9), time adjuncts (10) and locative adjuncts / goals (6, 11). Japhug text examples from each category are presented here to facilitate comparison with Tibetan and Chinese examples in the following sections.

\begin{tabular}{|c|c|c|}
\hline andzi & $\left.c^{h} \mathbf{u}-s \gamma-\gamma n d a\right]$ & nuu \\
\hline
\end{tabular}

'What is used to ram a bullet (into the muzzle of the gun) is called a ramrod.' (28-CAmWGdW, 55)

(8) $[\mathbf{u}-\mathbf{s} \boldsymbol{\gamma}-\mathbf{f} \mathbf{f} \boldsymbol{\gamma t}]$

3SG-NMLZ:OBLIQUE-tell

tr-prtso

INDEF.POSS-child

pu-ku-fse

PST-NMLZ:S-be.like pjr-me $\quad q^{\text {he }}$ toe

IPFV.IFR-not.exist LNK LNK

\section{u- $\mathbf{c k i}$}

3SG-DAT

nura

DEM:PL

$\begin{array}{llll}\text { nu } & \text { t6u } & \text { nura } & \text { t6 } \\ \text { DEM } & \text { LOC } & \text { DEM:PL } & \text { what }\end{array}$

pjr-fert.

IFR-TELL

'She had no one (else) to tell it to, so she told the boy everything that had happened.' (140515 congming de wusui xiaohai, 77)

(9) t6e [uzo

ma

because

ku-fse,

NMLZ:S-be.like

ma

apart.from

amumi-nu

be.in.good.term:FACT-PL u-sr-rmumi]

3SG-NMLZ:OBLIQUE-be.in.good.terms DEM

ca ku-fse qazo ku-fse,

musk.deer NMLZ:S-be.like sheep NMLZ:S-be.like

uzo $c^{h_{0}}$ ku-naðtcur sujno,

it with NMLz:S-be.identical herbs

mr-ku-ndza nu ra $\mathbf{c}^{\mathbf{h}_{\mathbf{h}}}$ nu

NEG-NMLZ:A-eat DEM PL with DEM

t6e,

LNK

'The (animals) that are in good terms with the rabbit are many, it is in good terms with those that only eat grass, like musk deer, sheep or goats.' (04 qalal, 33-4)

(10) t6e numu zaka $[\mathrm{u}-\mathrm{s} \gamma-\mathrm{ji}] \quad$ nu-yu t6e

LNK DEM each 3SG-NMLZ:OBLIQUE-plant SENS-be LNK

'These are the (periods) when people plant each of these (crops).' (15 tChWma, 19)

(11) kuki

this

múj-rtas

NEG:SENS-deep

múj- $-k^{\mathbf{h}} \mathbf{u}$

NEG:SENS-be.able

'The water is not deep enough, there is not (enough) place for me to come' (2010-03, 4) nui drn

be.many:FACT

$\mathbf{t s}^{\mathrm{h}} \mathrm{\gamma t}$ goat

x6аj

grass 
Lexicalized instrumental or locational nouns derived from a transitive verb are often built from the sigmatic participle of the antipassive $\mathbf{r r}^{-},{ }^{3}$ as in z-rr-xsur 'wok' (from the verb xsur 'parch, fry') or z-rr-rrt 'writing implement (paper or pen)' (from the verb rrt 'write')

There are several clues indicating that the oblique participle prefixes in Rgyalrong languages are not recently innovated. First, outside of core Rgyalrong, there are fossilized traces of sigmatic nominalization prefixes with instrumental or locative value in Khroskyabs (Lai 2017: 511) and Tangut (Jacques 2014b: 256-257). Second, within Rgyalrong, these prefixes have many allophones and there are several lexicalized nouns derived from oblique participles, even as first element of compounds, like srqrac $\mathbf{c}^{\mathbf{h}}$ a 'alcohol to treat the guests' from $\mathbf{c}^{\mathbf{h}} \mathbf{a}$ 'alcohol' and srqrr-, the status constructus of the oblique participle sr-qru of the verb qru 'meet, greet (迎接)'. Third, there is no plausible source for this prefix, as if it were from a relator noun meaning 'place' for instance, it should have been grammaticalized as a suffix.

\subsection{Sigmatic Converbs and Gerunds}

Other non-finite verb forms in $\mathbf{s} \gamma$ - include purposive converbs, which combine an imperfective orientation prefix (12) and gerunds, with reduplicated verb stem and no possessive or orientation prefixes (13 and 14). They are formally identical to reduplicated participles and are transparently grammaticalized from them (Jacques 2014c: 272-273, Grossmann et al. 2018).

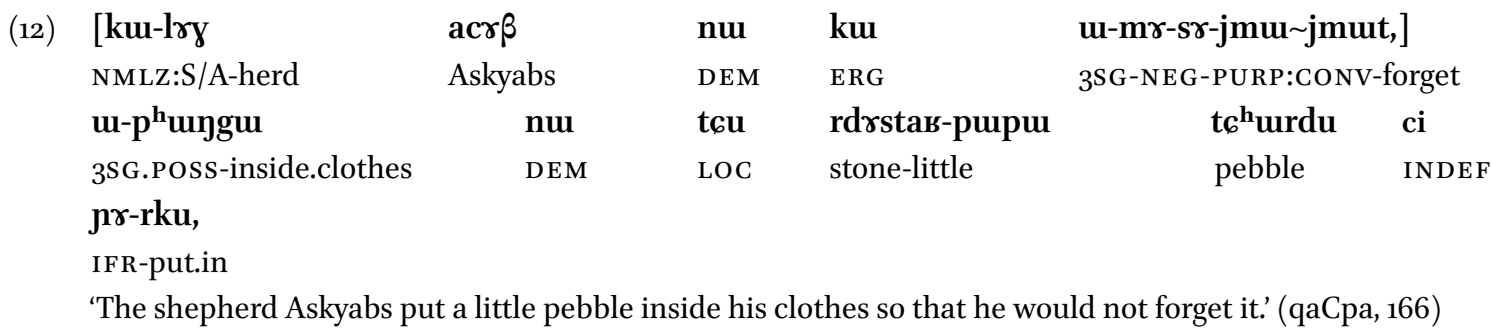

The gerund generally means simultaneous action, without any obligatory argument coreference between the gerund clause and the main clause, as shown by (13), where the verb in the gerund clause is intransitive, and its subject u-qom 'her tears' is not even an argument of the main clause (however, the transitive subject of the main clause is coreferent with the third person possessor of u-qom).

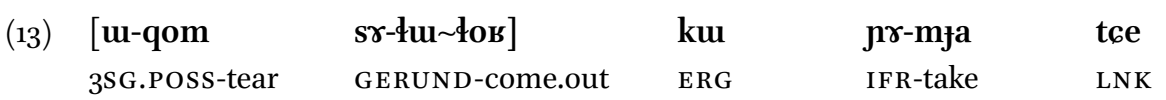

'She took it (from hear mother's hand) while her tears flowed' (140428 mu e guniang, 31)

Most commonly however, the subject of the gerund clause is coreferent with that of the finite verb in the main clause, as in (14). Note the absence of ISG person indexation on the gerund, as opposed to the finite verb ku-rrzit-a.

3 This antipassive prefix originates from the reanalysis of the denominal $\mathbf{r}$ - derivation of deverbal nouns (Jacques 2014a). 


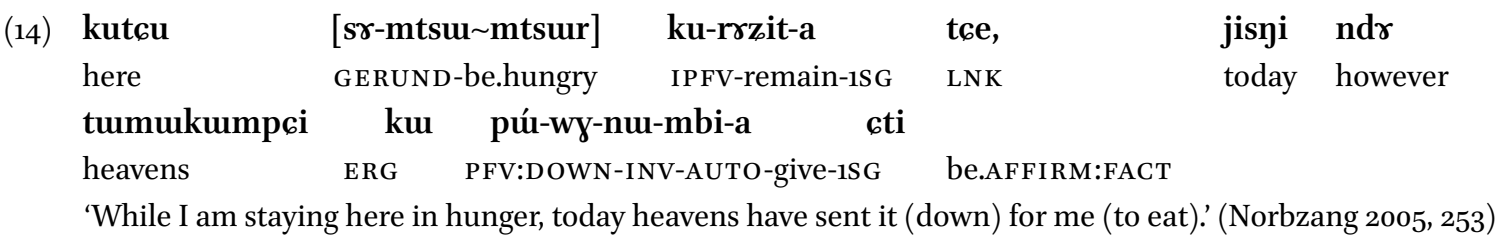

The gerund is also used to describe a background situation, as in (15).

(15) $[\mathrm{nu}$

DEM

pjr-ra

IFR.IPFV-have.to

\author{
sr-rku rkun] \\ GERUND-be.few \\ tce
}

LNK zo

EMPH

tr-prtso

INDEF.POss-child

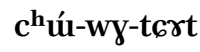

IPFV-INV-take.out

'One had to raise children with little (while food and clothes were few).' (140426 tApAtso kAnWBdaR, 5)

The gerund also occurs in a lexicalized expression with a specific meaning, for instance the gerund sr-xtcu-xtci from xtci 'be small' can mean 'when X was young, since childhood'.

\section{Tibetan}

Tibetan, ${ }^{4}$ like Khroskyabs, is a language where the prefixes corresponding to syllabic prefixes in core Rgyalrong languages have become simple consonants, without a phonemic vowel. As a result of the dramatic syllabic contraction that occurred in proto-Tibetan, much of the archaic morphology has become obscured.

\subsection{Velar Nominalization}

The complementary distribution of velar $\mathbf{g}$ - and dental $\mathbf{d}$ - preradicals in Tibetan, an observation which Hill (2011) ascribes to Saskya Pandita but which was first pointed out in modern scholarship by Li (1933), suggests that velar presyllables have been dissimilated to dentals ( $\left.{ }^{*} \mathbf{k} \boldsymbol{-}-\boldsymbol{~} \rightarrow \mathbf{d}-\right)$ before velars and labials, and that dental presyllables have been dissimilated to velars ( ${ }^{*} \mathbf{t} \mathbf{-}^{-} \rightarrow \mathbf{g}$-) before dentals. There is no way to distinguish between *kə- and *tə- presyllables from Tibetan alone, except before initial $\mathbf{r}$ - (and perhaps l-), where no dissimilation took place. ${ }^{5}$

A certain number of examples of $\mathbf{g}$ - or $\mathbf{d}$ - preinitials, often together with a -n, - $\mathbf{d}$ or -s suffix (forming a circumfix like the active participle in Limbu, example 5 in $§ 2.1$ ) derive nouns from verbs or adjectives, with either action nominal or subject nominal meaning (Jacques 2014d).

Examples with the g-allomorph include the following:6

4 This section presupposes accepted knowledge concerning Tibetan historical phonology and morphology (Li 1933; Coblin 1976; Hill 2011, 2014a), and obvious alternations (such as aspiration) are not commented on. The transcription of Tibetan adopted follows Jacques (2012d).

5 As a consequence, it is possible that the prefix $\mathbf{d}$-/g-in some of the examples below alternatively reflects the cognate of the action nominalization / degree nominalization tu-prefix in Japhug, on which see Jacques (2014a) and Jacques (2016a: 233236), found in the form u-tu-rnas 'its depth' in example (11).

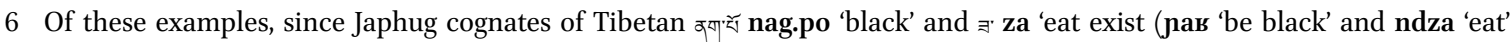
respectively), the velar nominalized forms गावग' gnag.pa 'black ox' and गचन्व gzan 'food (for animals)' have Japhug 


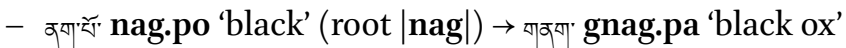

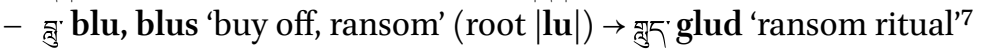

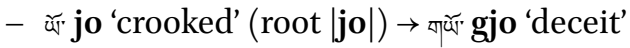

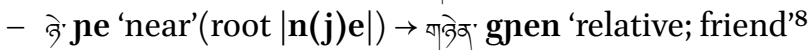

- 亏̆ no 'buy'(root $\mid$ no $\mid) \rightarrow$ गाॅ̆ gnod 'price (of a bride)'

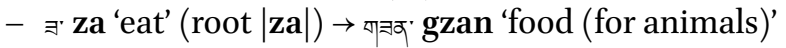

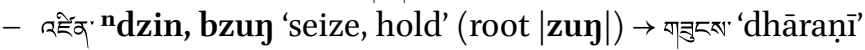

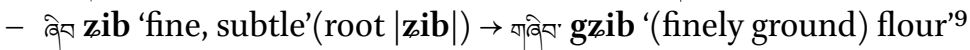

The example অ!־त' gzuys 'dhāraṇī' is evidence that the d/g-...-s circumfix was still marginally productive in the imperial period, as it is a calque from the Sanskrit dhṛ 'hold' (the root from which dhāraṇi derives), and must postdate the introduction of Buddhism.

In addition, Tibetan 行 gzob, translated in Zhang (1993) as 烧焦 ; 火烧的恶臭 'burn; smell of singeing', could be cognate with the Japhug irregular velar nominalization yndzr $\beta$ 'disastrous fire' (Table 1). Note however the attestation of лा̆̄ gzob in the glossary studied by Li (1962) in (16) corresponding to Chinese皆被焚燒火災滅後灰燼不現及至餘影亦不可得.

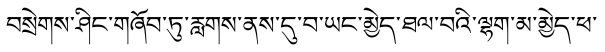

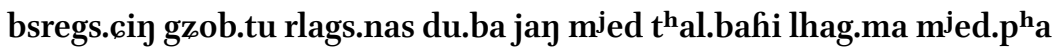

$$
\begin{aligned}
& \text { '(completely) burnt and destroyed in a fire, not even leaving smoke or ashes' }
\end{aligned}
$$

In this passage, गाॅ̆ gzob corresponds to 火災, with exactly the same meaning as the Japhug noun. The

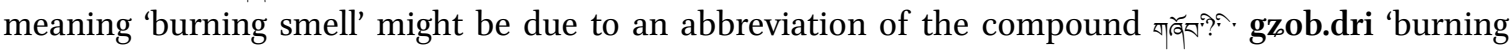
smell' in compounds. If this etymology is correct, the use of चाॅ̆ gzob as a verb is due to zero conversion.

Examples of the d-allomorph (with verb roots in velar and labial initials) include the following:

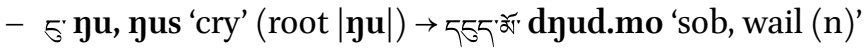

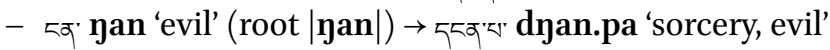

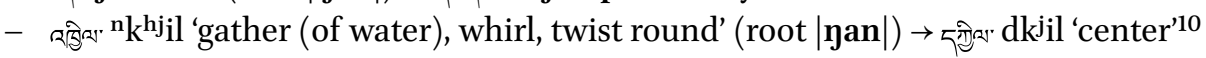

counterparts (ku--лав 'black one, the one which is black' / -ұрав 'disaster' and kr-ndza 'eating; food'). These are however parallel formations, and do not reflect common inheritance.

7 Concerning this ritual, see Karmay (1991).

8 Note the exact Japhug cognate tu-yji 'friend, ally'; the verb root केे ne 'near' does not exist in Japhug, and only the derived noun has been preserved.

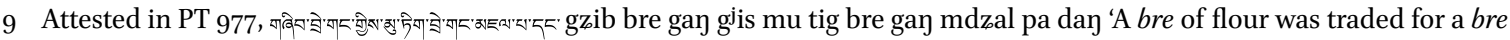
of pearls' (Silk 2018: 430).

10 The meaning 'center' would be derived from a older meaning 'confluence'. The verb a疋a n $\mathbf{k}^{\mathrm{hj}} \mathrm{jl}$ 'gather, whirl' is used for instance to refer to water gathering into a pond. 


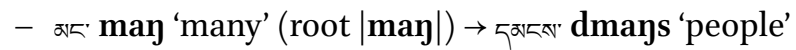

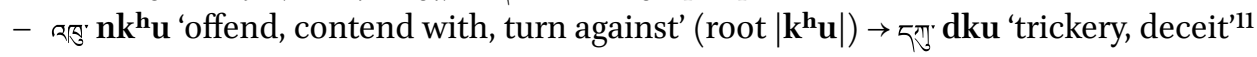

It is conceivable that some of the $\mathbf{g}$-/d- prefixes found in the Tibetan verbal system, in particular in the future tense, may be participial form that entered the finite system. This question goes however beyond the scope of this paper.

\subsection{Sigmatic Nominalization}

Examples of oblique nominalization by sigmatic prefix in Tibetan are not many. The clearest ones, unsurprisingly, involve the instrumental nouns (the function illustrated by 7 in Japhug). As in the case of the velar nominalization prefix, as noted above, the sigmatic nominalization prefix generally occurs together with a suffix -d or -s, as in «্গ s-no-d 'vessel'.12

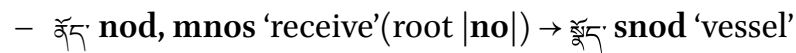

- $25 ु 5$ ' bud, bus 'blow' (root $\mid$ bu $\mid) \rightarrow$ 젇ㄷ' sbud.pa 'bellows'

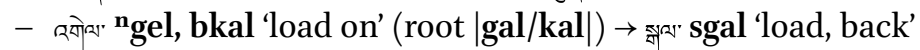

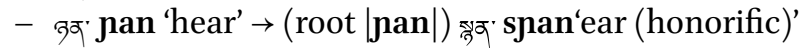

The examples above are not problematic; note that in the case of the honorific noun 잠. snan 'ear', we possibly have a calque from Sanskrit śrava- 'hearing', which is attested in the sense of 'ear' in Classical Sanskrit. The adjective 짬 syan 'euphonious' is also derived from prefix, the cognate of the proprietive prefix sr-in Japhug, which is found in examples such as $\mathbf{m t s}^{\mathbf{h}} \mathbf{\gamma m}$ 'hear' $\rightarrow$ sr-mtsh $r$ m 'audible' (Jacques 2012b).

Nouns of location derived by the prefix s- (corresponding to Japhug examples such as 6 and 11) include the following:

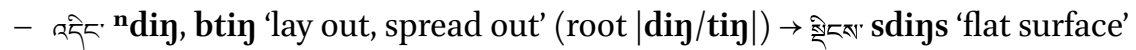

- इ㐫- dgar, bkar 'pitch (tent)' (as in gur bkar 'pitch a tent', root $|\operatorname{gar} / \mathbf{k a r}|) \rightarrow$ 쥦.' sgar 'encampment'

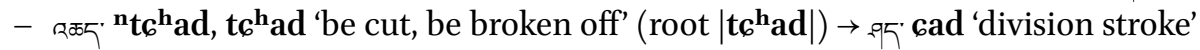

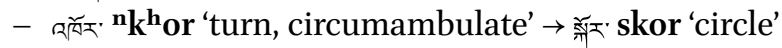

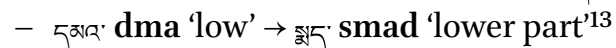

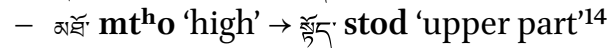

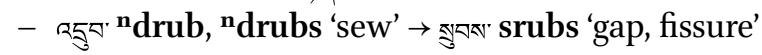

See Bialek (2016: 150-1) for the philological study of this noun in Old Tibetan texts and the proposal of a derivation from

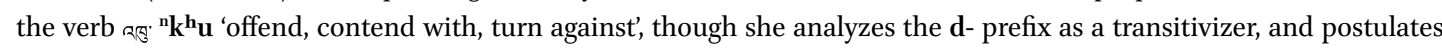
that the noun derives from an unattested transitive verb *dku 'bend, make crooked'.

Another type of derivation involving s-...-d circumfixes is found in Tibetan: the collective noun derivation found with

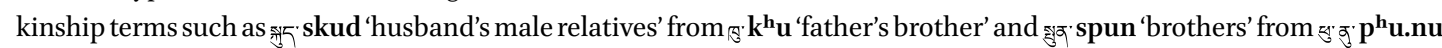
'elder and younger brothers' (Nagano 1994). This formation is unrelated to the sigmatic nominalization described in this section. tion. Note also the adverb अ邓' mar 'down' from the same root, with a terminative -r suffix.

This example suggests that the pre-Tibetan cluster *smt- was simplified as st-. 


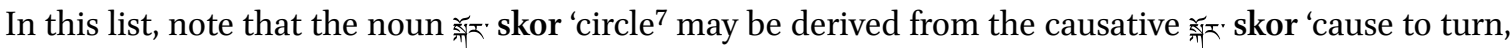
surround, circumambulate' and therefore not be an example of a sigmatic nominalization prefix. The same explanation is not possible for the other examples, however.

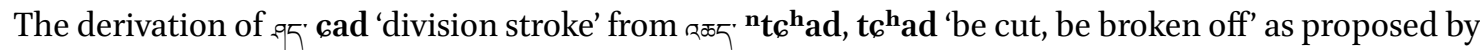
$\mathrm{Li}$ (1933: 141) ${ }^{15}$ with a proto-form * $\mathbf{s - t 6 a d ~} \rightarrow \mathbf{c a d}$ is a non-trivial example of sigmatic nominalization; this word would mean literally 'breaking place (when reading)'.

In addition to these two main categories, there are two potential isolated examples of sigmatic nomi-

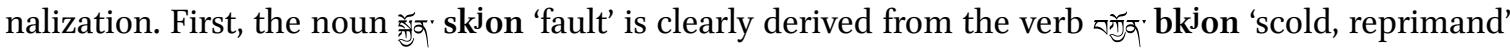
(whose b- may be a frozen past tense prefix); the semantic relation between the verb and the noun may be that of cause, a type not attested in Japhug.

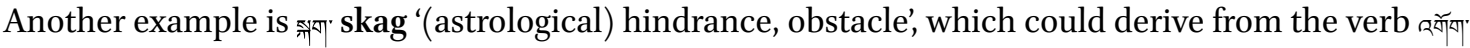
ngog, bkag 'hinder,', 16 a temporal nominalization, like the Japhug example (10). This is the only example from verbs with voicing alternation (on which see Hill 2014b) where the oblique nominalization is based on the unvoiced alternant (the base form according to Jacques 2012c).

\section{$4 \quad$ Old Chinese}

Reconstruction of morphology in Old Chinese (OC) is a much more delicate enterprise that in Tibetan, since even the mere existence of clusters has to be reconstructed (Gong and Lai 2017). Nevertheless, there are potential cases of nominalization prefixes in Old Chinese, whose interpretation depends on the reconstruction system followed.

\subsection{Velar Nominalization}

Evidence for velar nominalization in Old Chinese is slim, but not nonexistent. Baxter and Sagart (2014: 57) suggest the following possibilities:

- 方 pjag 'square' ( $\left.{ }^{*} \mathrm{C}-\mathbf{p a g}\right) \rightarrow$ 匡 $\mathbf{k}^{\mathbf{h}} \mathbf{j w a \eta}$ 'square basket' ("k-p $\left.{ }^{\mathbf{h}} \mathbf{a \eta}\right)$

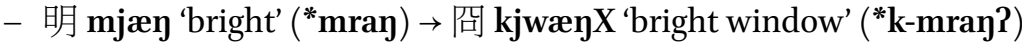

- 威 Pjwij 'awe-inspiring' ( ${ }^{*}$ ?uj $) \rightarrow$ 鬼 kjwijX 'ghost' ( ${ }^{*} k-$ Puj? $)$

15 Note that while Li Fang-kuei's sound law *s-t6- $\rightarrow$ 6- is certainly correct (as pointed out by Abel Zadoks in an unpublished manuscript for instance, the numeral ji.cu 'twenty' can be explained as an instance of this sound change, the proto-form being *nis-tcu, perfectly parallel to sum.tcu 'thirty'), some of his examples have to be abandoned. For instance, he argues

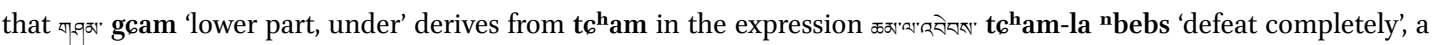

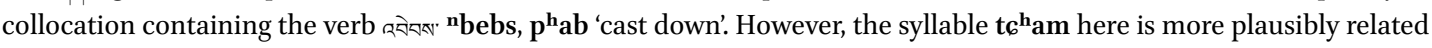

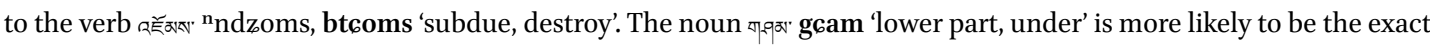
cognate of Japhug tr-zrrm 'root' and Chinese 參 sim $\leftarrow$ *srom 'plant root' (see Jacques 2015), with the sound laws *sr- $\rightarrow$ 6- and *tə- $\rightarrow$ g- before coronal consonants (on the latter, see the discussion in $\S$ 3.1); the g- would reflect the indefinite possessor prefix (the noun 'root' being an inalienably possessed noun).

16 Another possibility would be the adjective बगा $\mathbf{k}^{\mathbf{h}} \mathbf{a g}$.po 'difficult, hard', if ancient attestations can be brought to light.

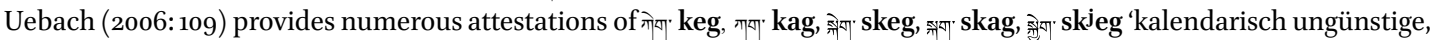
gefährlische Zeit, Hindernis, drohendes Unglück'. The s-less forms are found as second members of compounds, as in

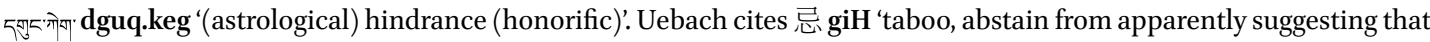
the Tibetan word could be related; this is impossible for phonological reasons (voiced initial and absence of coda). 
It is however likely that some Old Chinese *kə- presyllables disappeared without observable traces in Middle Chinese, as shown by the data in Table 4.47 in Baxter and Sagart (2014: 153), where data from ancient loanwords into Vietic and Lakkia demonstrate the presence of a velar preinitial element in words such has 賊 dzok 'bandit' (Ruc kəcsk). As a consequence, most potential traces of velar nominalization prefixes may have been lost by the effects of sound change, though the study of OC loanwords in Kra-Dai, Vietic and Hmong-Mien may provide further examples.

\subsection{Sigmatic Nominalization}

Sagart (1999: 73) proposed the following examples of the *s- nominalization prefix (here I keep the original reconstruction, ${ }^{17}$ without conversion to the system of Baxter and Sagart 2014, as none of these examples has become invalid in the new reconstruction).

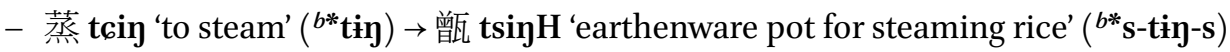

- 祂 jet, jejH 'to pull' ( ${ }^{b *}$ lat(-s) $) \rightarrow$ 革世 sjet 'leading string' ( ${ }^{b *}$ s-lat)

- 踒 yet 'to bite, gnaw' ( ${ }^{* *}$ yet) $\rightarrow$ 楔 set 'wedge, piece of wood between the teeth of a corpse' $\left(a^{*}\right.$ s-yet)

- 身寸 zek, zæH 'to shoot' ( ${ }^{* *} \mathbf{m}$-lak(-s); the *-s suffix here has an antipassivizing function, see Jacques to appear $) \rightarrow$ 榭 zjæH 'open hall for archery exercises' $\left({ }^{*} \mathbf{s}-\mathbf{l a k}-\mathbf{s}\right)^{18}$

- 侍 dziH 'to accompany, wait upon' ( $\left.{ }^{b *} \mathbf{d i}(\mathbf{P})-\mathbf{s}\right) \rightarrow$ 寺 ziH ‘servant, eunuch' ( $\left.{ }^{* *} \mathbf{s}-\mathbf{d i}(\mathbf{P})-\mathbf{s}\right)$

- 食 zik 'to eat' ( $\left.{ }^{* *} \mathbf{m}-\mathbf{l i k}\right) \rightarrow$ 食 ziH 'food' ( ${ }^{b *} \mathrm{~s}$-lik-s)

Additional examples are presented in Baxter and Sagart (2014:56) and Sagart and Baxter (2012). Some of these nouns, for instance 星 sey 'star' and 席 zjek 'mat', are derived from a root that is only attested in derived verbal forms.

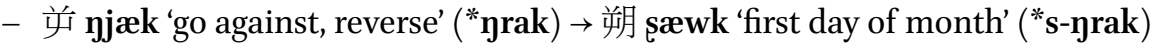

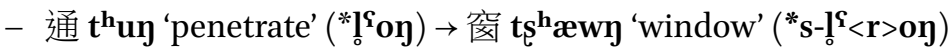

- 亡 mjay 'flee; disappear; die' ( $\left.{ }^{*} \mathbf{m a y}\right) \rightarrow$ 喪 say 'mourning, burial' ( ${ }^{*} \mathbf{s}-\mathbf{m} \mathbf{s}$ ay)

- 以 jiX 'take, use' (*lə?) $\rightarrow$ 鉛 ziX 'handle of plow or sickle' (*'sə.lə?)

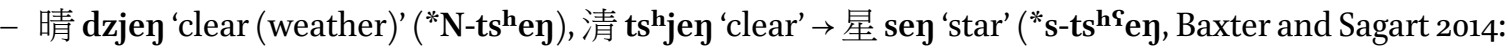
$139)^{19}$

17 One difference between Sagart (1999) and Baxter and Sagart (2014) is the way A-type (division I, II and IV) and B-type (division III and a few division II) syllables are represented: in the former the superscript $a$ and $b$ are added before the main syllable, while in the latter, following Norman (1994), A-type syllables are reconstructed with pharyngealization and B-type syllables without pharyngealization.

18 Note that the locative noun 榭 zjæH is based on the antipassive form of the verb, as we find in Japhug $(\S 2.2)$.

19 Even if one accepts the sound change * $\mathbf{s}-\mathbf{t s}^{\mathbf{h}_{-} \rightarrow \mathbf{s}}$-, analyzing 星 sey 'star' as a locative nominalization * $\mathbf{s}-\mathbf{t s}^{\mathbf{h} \mathbf{s}} \mathbf{e y}$ from a root *ts ${ }^{\mathbf{h}} \mathbf{e y}$ attested by 晴 dzjey 'clear (weather)' and 清 $\mathbf{t s}^{\mathbf{h}} \mathbf{j e \eta}$ 'clear' is problematic. Although the graphs belong to the same phonetic series and the affricate onset is supported by Min data, the semantic difference is considerable, since these adjectives never mean 'bright' and are not associated with stars. The only way to salvage the hypothesis would be to suppose a locational/temporal noun 'clearing (in the night sky)' $\Rightarrow$ 'starry sky' (night sky without any cloud), from which 'star' would be a singulative. The meaning 'starry sky' for 星 sey may be attested, as in the following passage from the poem 定 之方中 Ding Zhi Fang Zhong (50) in the Shijing: 靈雨既零、命彼倌人。星言夙駕、說于桑田。'When the good rains had fallen, He would order his groom, By starlight, in the morning, to yoke his carriage, And would then stop among the 
- 署 dzoH 'toplace; position' ( ${ }^{*} \mathbf{m}-\mathbf{t a}$ ?-s), 緒 zjoX'arrange in order' ( $\left.{ }^{*} \mathbf{s}-\mathbf{m}-\mathbf{t a P}\right)$, 著 tjak 'to place' $\left({ }^{* *} \mathbf{t}<\mathbf{r}>\mathbf{a k}\right)$ $\rightarrow$ 席 zjek 'mat' ("s-m-tAk, Baxter and Sagart 2014: 61)

- 除 djo 'remove' (*[1]<r>a) $\rightarrow$ 鋤 dzjo 'hoe' (*s-[l] $<\mathbf{r}>\mathbf{a}$, Baxter and Sagart 2014: 81)

- 匀 jwin 'even, uniform' ( $\left.{ }^{*}[\mathbf{N}-\mathbf{q}]^{\mathbf{w i}}[\mathbf{n}]\right) \rightarrow$ 旬 zwin 'ten-day cycle' $\left({ }^{*} \mathbf{s}-\mathbf{N}-\mathbf{q}^{\mathbf{w}} \mathbf{i}[\mathbf{n}]\right.$, Baxter and Sagart 2014: 127)

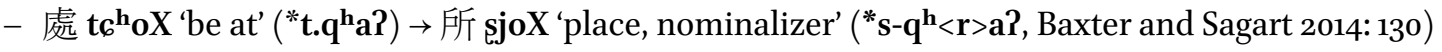

- 圓 hjwen 'round' ( $\left.{ }^{*} \mathbf{G}^{\mathbf{w}}<\mathbf{r}>\mathbf{e n}\right) \rightarrow$ 旋 $\mathbf{z j w e n H}$ 'whorl of hair on the head' ( ${ }^{*} \mathbf{s}-\mathbf{G}^{\mathbf{w}} \mathbf{e n}-\mathbf{s}$, Baxter and Sagart 2014: 141$)^{20}$

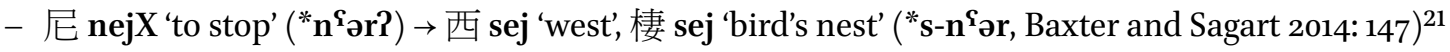

While some of sound changes involved are not universally accepted, in particular ${ }^{*} \mathbf{s}-\mathbf{t s}^{\mathbf{h}} \mathbf{}_{-} \rightarrow \mathbf{s}$ - and Li Fang-Kuei's (Li 1971) idea of * $\mathrm{sN}-\rightarrow$ *s- (see the debate between Mei 2012 and Sagart and Baxter 2012), the change *sl- $\rightarrow$ z- in B type syllables is least controversial. ${ }^{22}$ Even if we exclude all examples with controversial onsets for the sake of argument, we still have good examples of locative (榭 zjæH), comitative (寺 ziH) and instrumental (鉛 ziX) nominalizations, comparable to Japhug examples (6, 11), (9) and (7) respectively. The case of 食 $\mathbf{z i H}$ 'food' is more doubtful because there is a causative 食 $\mathbf{z i H}$ 'feed' from which it could derive by zero derivation, and also because an oblique nominalization of 'eat' should rather mean 'eating place' or 'instrument used for eating', not 'food'.

These three examples of sigmatic nominalization (榭 $\mathbf{z j æ H}$, 寺 $\mathbf{z i H}$, 鈶 $\mathbf{z i X}$ ) are not the only ones that seem relatively straightforward. Without committing to a particular reconstruction system, if we accept Li Fangkuei's (Li 1971) reconstruction of s + nasal onsets, and Bodman's (1969) hypothesis of OC dental affricates originating from clusters in ${ }^{*} \mathrm{~s}-\left({ }^{*} \mathrm{~s}-\mathrm{T}-\rightarrow{ }^{*} \mathrm{TS}-\right)$, three examples of instrumental nominalization (楔 set 'wedge', 曾瓦 tsigH | earthenware' and 鋤 dzjo 'hoe') and three examples of temporal/locative nominalization (朔 sæwk, 喪 sag, 棲 sej) are fairly convincing.

A possible example of sigmatic converb (parallel to the gerund in Japhug, $\S 2.3$ in examples such as 13 to 15) in Old Chinese is the conjunction 雖 swij 'although'. This conjunction is already attested in the Shijing as in (17), where it occurs in opposition to the copula 維 jwij in the main clause.

（17）周雖舊邦, 其命維新

mulberry trees and fields.' (translation by Legge). Karlgren (1974:33) translates it as 'when it cleared during the night, early he yoked his carriage'.

From a phonological point of view, reconstructing * s-ts ${ }^{\mathbf{h}_{-}}$is not the only logical possibility to account for the s- to *tš ${ }^{\mathbf{h}}$ correspondence between MC and proto-Min, and the xiesheng contacts with words in affricates. For instance, a reconstruction *tว-s ${ }^{\text {sey }}$ with a dental presyllable, fusing with the main syllable in the ancestor of Min, could also be considered. In this hypothesis, an etymological relationship with the words meaning 'clear' would have to be abandoned.

20 The word 旋 zjwenH is more likely to be a nominalization by qùshēng from the verb 旋 zjwen 'revolve, turn' (on which see Downer 1959, Jacques 2016c).

21 This example, also discussed in Sagart (2004) and Nohara (2018), would have a direct Japhug equivalent srz-nuna 'resting place'. These are however not real cognate, since the Japhug word can be productively formed from the verb numa 'to rest'.

22 On the voicing of preinitial *s- in contact with a voiced lateral, see the typological discussion in Gong (2016), with evidence from Rgyalrongic and Tibetic languages. 
'Though Chow is an old state, its (heavenly) appointment is new.' (235; Daya, Wenwang, Karlgren 1974: 185)

An etymological relationship between 雖 swij 'although' and 維 jwij 'be' is likely given their occurrence in the same phonetic series. ${ }^{23}$ A copula with a converbial *s- prefix would mean 'while being Xxx', a form that can have a concessive meaning in appropriate contexts (in the same way that English 'while', originally a temporal conjunction, has also become concessive) and could have become restricted in this usage.

Baxter and Sagart reconstruct 雖 $\mathbf{s w i j}$ as ${ }^{*} \mathbf{s}-\mathbf{q}^{\mathbf{w}} \mathbf{i j}$ and 維 $\mathbf{j w i j}$ as ${ }^{*} \mathrm{G}^{\mathbf{w}} \mathbf{i j}$, and do not imply a morphological relationship between the two; in their system, the expected outcome of * $\mathbf{s}-\mathbf{G}^{\mathbf{w}} \mathbf{i j}$ would be $\nmid \mathbf{z w i j}$. There are several ways around this problem; Jacques (2000) reconstructs 雖 swij as *s-tə-wuj and 維 jwij as *tə-wuj, using a system based on Sagart (1999); in this hypothesis, the presence of a *tə- preinitial, reconstructed here to account for the xiesheng relationship with 推 $\mathbf{t}^{\mathbf{h}}$ woj (from ${ }^{*} \mathbf{t}^{\mathbf{h}} \mathbf{u j}$ ), accounts for the absence of voicing. If the reconstruction of a preinitial in this word is not accepted, it remains possible to suppose that, given the fact that this converbial prefix was probably not lexicalized at the same time as the other *s- prefixes, different sound laws apply.

Although the existence of sigmatic nominalization in Old Chinese is less immediately obvious than in Tibetan, the number of examples is of a comparable order.

\section{$5 \quad$ Conclusion}

The Tibetan and Chinese data presented in this paper support the idea that the sigmatic prefixes of Rgyalrong languages are not a Rgyalrongic innovation, but rather the preservation of prefixes that used to exist in the literary languages, but of which only fossil traces remain in the earliest attested stages of these languages. It is likely that traces of the same prefixes can be found elsewhere in the Trans-Himalayan family, though only few branches preserve unequivocal traces of the preinitials. ${ }^{24}$

It is hoped that the Japhug data provided in this paper will be useful to researchers of Old Chinese and Tibetan to look for additional examples of sigmatic oblique nominalization, and better evaluate the precise semantics of proposed etymologies: since the sigmatic participles are fully productive in Japhug, this language allows a finer-grained understanding of the use of this derivation than languages where only fossilized remnants can be identified.

The morphology-rich Rgyalrong languages have a role in the reconstruction of Trans-Himalayan morphology comparable to that of Sanskrit in IndoEuropean and Arabic in Semitic: their exuberant productivity offers an living model to build hypotheses on the traces of morphology in lesser-endowed languages.

23 See also Behr (2006) for further philological evidence for an etymological relationship between 雖 swij and 維 jwij. Behr views the *s- prefix as a causative, an interpretation that is not impossible, but is more complex than that proposed here.

24 In particular, a possibly related nominalization prefix, which has the allomorphs chya-, sha- and sa-, is found in Jinghpo (Dai 1990: 3-4). However, it does not derive oblique nominals, and this comparison requires more investigation. 


\section{Acknowledgement}

I would like to thank José Andrés Alonso de la Fuente, Nathan W. Hill, Laurent Sagart and three anonymous reviewers for useful comments.

\section{References}

Baxter, William H. and Laurent Sagart. 2014. Old Chinese: a new reconstruction. Oxford: Oxford University Press.

Baxter, William H. III. 1992. A Handbook of Old Chinese Phonology. Trends in Linguistics, Studies and Monographs 64. Berlin: Mouton de Gruyter.

Behr, Wolfgang. 2006. Morphological notes on the Old Chinese counterfactual. Bochumer Jahrbuch zur Ostasienforschung, 30:55-88.

Bialek, Joanna. 2016. Side, stench, remnant, plot, oath, and craftiness - the semantic 'capacity' of the OT dku*. Revue d'études tibétaines, 35:115-167.

Bodman, Nicholas. 1969. Tibetan sdud "folds of a garment", the character 卒, and the ST-hypothesis. Bulletin of the Institute of History and Philology, 39 (2):327-346.

Coblin, Weldon South. 1976. Notes on Tibetan Verbal Morphology. T'oung Pao, 62:45-70.

Dai, Qingxia. 1990. 景颇语语法J̌ngpōyǔ yǔfă (A grammar ofJinghpo). Běijīng: Mínzú chūbǎnshè.

DeLancey, Scott. 2014. Second person verb forms in Tibeto-Burman. Linguistics of the Tibeto-Burman Area, $37(1): 3-33$.

DeLancey, Scott. 2015. Adjectival constructions in Bodo and Tibeto-Burman. In Mark Post, Stephen Morey, and Scott DeLancey, editors, Language and Culture in Northeast India and Beyond - in honor of Robbins Burling, 41-56. Canberra: Asia-Pacific Linguistics.

Downer, G. B. 1959. Derivation by tone-change in Classical Chinese. Bulletin of the School of Oriental and African Studies, 22(1/3):258-290.

van Driem, George. 1987. A Grammar of Limbu. Berlin and New York: Mouton De Gruyter.

Gong, Xun. 2016. Prenasalized reflex of Old Tibetan <ld-> and related clusters in Central Tibetan. Cahiers de Linguistique - Asie Orientale, 45(2):127-147.

Gong, Xun. 2017. 嘉线语组语言与上古汉语的形态学. In Haeree Park and Shaoxuan Cheng, editors, 古文 字与汉语历史音韵学, 复旦中华文明研究专刊, 134-156. Shanghai: Fudan daxue chubanshe.

Gong, Xun \& Yunfan Lai. 2017. Consonant clusters. In Rint Sybesma, Wolfgang Behr, Yueguo Gu, Zev Handel, C.-T. Huang, and James Myers, editors, Encyclopedia of Chinese Language and Linguistics, volume 1, 665-672. Leiden: Brill.

Grossmann, Eitan, Guillaume Jacques, and Anton Antonov. 2018. A cross-linguistic rarity in synchrony and diachrony: adverbial subordinator prefixes exist. STUF - Language Typology and Universals, $71(4): 513-538$.

Hill, Nathan W. 2011. An inventory of Tibetan Sound Laws. Journal of the Royal Asiatic Society, 21(4):441-457.

Hill, Nathan W. 2014a. Tibetan. In Rochelle Lieber and Pavol Štekauer, editors. The Oxford Handbook of Derivational Morphology, 620-630. Oxford: Oxford University Press.

Hill, Nathan W. 2014b. A note on voicing alternation in the Tibetan verbal system. Transactions of the Philological Society, $112(1): 1-4$.

Jacques, Guillaume. 200o. The character 維, 惟, 唯 ywij and the reconstruction of the 月旨 Zhi and 微 Wei rhymes. Cahiers de Linguistigue - Asie Orientale, 29(2):205-222.

Jacques, Guillaume. 2012a. Agreement morphology: the case of Rgyalrongic and Kiranti. Language and Linguistics, 13(1):83-116. 
Jacques, Guillaume. 2012b. Argument demotion in Japhug Rgyalrong. In Katharina Haude and Gilles Authier, editors, Ergativity, Valency and Voice, 199-226. Berlin:Mouton De Gruyter.

Jacques, Guillaume. 2012c. An internal reconstruction of Tibetan stem alternations. Transactions of the Philological Society, 110(2):212-224.

Jacques, Guillaume. 2012d. A new transcription system for Old and Classical Tibetan. Linguistics of the TibetoBurman Area, 35(2):89-96.

Jacques, Guillaume. 2014a. Denominal affixes as sources of antipassive markers in Japhug Rgyalrong. Lingua, 138:1-22.

Jacques, Guillaume. 2014b. Esquisse de phonologie et de morphologie historique du tangoute. Leiden: Brill.

Jacques, Guillaume. 2014c. Clause linking in Japhug Rgyalrong. Linguistics of the Tibeto-Burman Area, $37(2): 263-327$.

Jacques, Guillaume. 2014d. On Coblin's law. In Richard VanNess Simmons and Newell Ann Van Auken, editors, Studies in Chinese and Sino-Tibetan Linguistics, 155-166. Taipei: Institute of Linguistics, Academia Sinica.

Jacques, Guillaume. 2015. On the cluster *sr in Sino-Tibetan. Journal of Chinese Linguistics, 43(1):215-223.

Jacques, Guillaume. 2016a. Complementation in Japhug. Linguistics of the Tibeto Burman Area, 39(2):222-281.

Jacques, Guillaume. 2016b. Subjects, objects and relativization in Japhug. Journal of Chinese Linguistics, 44(1):1-28. Jacques, Guillaume. 2016c. How many *-s suffixes in Old Chinese? Bulletin of Chinese Linguistics, 9(2):205-217.

Jacques, Guillaume. 2018. Generic person marking in Japhug and other Rgyalrong languages. In Fernando Zúñiga and Sonia Cristofaro, editors, Diachrony of hierarchical systems, 403-424. Amsterdam: John Benjamins.

Jacques, Guillaume. n.d. Antipassive derivations in Sino-Tibetan/Trans-Himalayan and their sources. In Katarzyna Janic, Denis Creissels, and Alena Witzlack-Makarevich, editors, The multifaceted nature of Antipassive. Amsterdam: Benjamins. to appear.

Jacques, Guillaume, Anton Antonov, Yunfan Lai, and Lobsang Nima. Stau (Ergong, Horpa). 2017. In Graham Thurgood and Randy LaPolla, editors, The Sino-Tibetan Languages (2nd edition), 597-613. London: Routledge.

Karlgren, Bernhard. 1974. The book of Odes. Stockholm: Museum of Far Eastern Antiquities.

Karmay, Samten G. 1991. L'homme et le bœuf: Le rituel de glud ('rançon'). Journal Asiatique, 279(3-4):327-381.

Konnerth,Linda. 2014. A grammar of Karbi. PhD thesis, University of Oregon.

Konnerth, Linda. 2016. The Proto-Tibeto-Burman *gV-nominalizing prefix. Linguistics of the Tibeto Burman Area, $39(1): 3-32$.

Lai, Yunfan. 2017. Grammaire du khroskyabs de Wobzi. PhD thesis, Université Paris III.

Li, Fang-Kuei. 1933. Certain Phonetic Influences of the Tibetan Prefixes upon the Root Initials. Bulletin of the Institute of History and Philology, 6(2): 135-157.

Li, Fang-Kuei. 1962. A Sino-Tibetan Glossary from Tun-huang. T'oung Pao, 49 (4/5):233-356.

Li, Fang-Kuei. 1971. 上古音研究. The Tsing Hua Journal of Chinese Studies, 9 (1,2):1-61.

Mei, Tsulin. 2012. The causative *s- and nominalizing *-s in Old Chinese and related matters in Proto-Sino-Tibetan. Language and Linguistics, 13(1): 1-28.

Michailovsky, Boyd, Martine Mazaudon, Alexis Michaud, Séverine Guillaume, Alexandre Frangois, and Evangelia Adamou. 2014. Documenting and researching endangered languages: the Pangloss Collection. Language Documentation and Conservation, 8:119-135.

Nagano, Sadako. 1994. Note on the Tibetan kinship terms khu and zhang. Linguistics of the Tibeto-Burman Area, $17(2): 103-115$.

Nohara, Masaki. 2018. Old Chinese "west": *sn ər. Language and Linguistics, 19 (4):577-591.

Norman, Jerry. 1994. Pharyngealization in Early Chinese. Journal of the American Oriental Society, 114:397-408.

Sagart, Laurent. 1999. The roots of Old Chinese. Amsterdam and Philadelphia: Benjamins. 
Sagart, Laurent. 2004. The Chinese Names of the Four Directions. Journal of the American Oriental Society, 124.1:69-76.

Sagart, Laurent and William H. Baxter. 2012. Reconstructing the s- prefix in Old Chinese. Language and Linguistics, 13(1):29-59.

Silk, Jonathan. 2018. A Present Future Foretold: The Ten Dreams of King Kṛkin in Pelliot tibétain 977. In Saddharmā mrtam, Festschrift für Jens-Uwe Hartmann zum 65. Geburtstag, 427-438. Vienna: Arbeitskreis dür tibetische und buddhistische Studien.

Sun, Jackson T.-S. 2006. 草登嘉戎語的關係句 Caodeng Jiarongyu de guanxiju (Relative clauses in the Tshobdun language). Language \& Linguistics, 7 (4):905-933.

Sun, Jackson T.-S. 2012. Complementation in Caodeng rGyalrong. Language and Linguistics, 13(3):471-498.

Sun, Jackson T.-S. 2014a. Sino-Tibetan: Rgyalrong. In Rochelle Lieber and Pavol Štekauer, editors, The Oxford Handbook of Derivational Morphology, 630-650. Oxford: Oxford University Press.

Sun, Jackson T.-S. 2014b. Typology of Generic-Person Marking in Tshobdun Rgyalrong. In Richard VanNess Simmons and Newell Ann Van Auken, editors, Studies in Chinese and Sino-Tibetan Linguistics: Dialect, Phonology, Transcription and Text, 225-248. Taipei: Institute of Linguistics, Academia Sinica.

Sun, Jackson T.-S. and Youjing Lin. 2007. Constructional Variation in rGyalrong Relativization: How To Make a Choice? In Pre-Conference Proceedings of the International Workshop on Relative Clauses, 205-226. Taipei: Institute of Linguistics, Academia Sinica.

Uebach, Helga. 2006. Wörterbuch der tibertischen Schriftsprache, volume 2. München: Verlag der bayerischen Akademie der Wissenschaften.

Yanmuchu. 2005. 论嘉戎语中 sa的语法功能及形式 (The grammatical function and form of the prefix sa- in Rgyalrong. 阿坝师范高等专科学校学报， 1 .

Zhang, Shuya. 2016. La phonologie et la morphologie du dialecte de Brag-dbar du rgyalrong situ. Université Paris III MA thesis.

Zhang, Yisun. 1993. Bod rgya tshig mdzod chen mo. Beijing: Mi rigs dpe skrun khang. 


\title{
原始名物化前缀在藏语和上古汉语中的痕迹
}

\author{
向柏霖 \\ 法国国立科学研究中心 \\ rgyalrongskad@gmail.com
}

提要

本文指出藏语和上古汉语中存在着原始名物化前缀的一些词汇化的例子, 这些前缀虽然在汉语和藏语中没 有清楚的语法功能, 但是在形态存古的嘉线语支语言当中还保留着能产性, 因此嘉线语支语言给我们提供 了分析其他语言的研究框架。

\section{关键词}

藏语 、上古汉语 、嘉线语支、基兰提语支、名物化、前缀 